Original Research Paper

\title{
Microalgae Diversity as a Bioindicator of Water Quality in Batujai Dam, Central Lombok
}

\author{
Hairunnadawiah $^{{ }^{*}}$, Khairuddin $^{1}$, Lalu Zulkifli ${ }^{1}$ \\ ${ }^{1}$ Biology Education, Faculty of Teacher Training and Education, Mataram University, Mataram, Indonesia.
}

\author{
Article History \\ Received : November $15^{\text {th }}, 2021$ \\ Revised : December 30 th 2021 \\ Accepted : January $20^{\text {th }}, 2022$ \\ Published : January $31^{\text {th }}, 2022$ \\ *Corresponding Author: \\ Hairunnadawiah, \\ Biology Education, Faculty of \\ Teacher Training and Education, \\ Mataram University, Mataram, \\ Indonesia. \\ Email: \\ hairunnadawah135@gmail.com
}

\begin{abstract}
Batujai Dam is one of the largest dams in Central Lombok with an area of 890 ha of inundated water. The water from the Batujai Dam is used for irrigation of agricultural land, flood control, freshwater fisheries and the development of micro-hydro power plants. Batujai Dam is also a reservoir for several rivers in Central Lombok, namely: the Leneng River, the Sade River and the Dodokan River. This function makes the Batujai Dam a place for the accumulation of various forms of pollutants carried by the inlet rivers. Microalgae is one of the ecological parameters that can function as a bioindicator of water quality. The purpose of this study was to determine the water quality in the Batujai Dam in terms of the microalgae diversity index and the measurement of environmental factors. Determination of sampling point and sampling time using purposive sampling method. Measurement of water quality is carried out by determining the diversity index and measuring environmental factors such as $\mathrm{pH}$, temperature, DO, BOD, phosphate and nitrate. Microalgae data for determining the diversity index was analyzed using the Microsoft Excel 2010 program. The results showed that the identified microalgae consisted of 5 classes, 16 orders and 40 species. The overall diversity index of microalgae in the Batujai dam is 1.712 with a DO value of 5.09 and a BOD of 4.0175. Based on these data, it can be concluded that the water quality in the Batujai Dam is in an unhealthy condition (lightly polluted). The allotment for the use of water from the Batujai Dam is suitable for freshwater fish farming, livestock and agricultural irrigation, and it is not recommended for drinking water sources and water recreation infrastructure/facilities.
\end{abstract}

Keywords: Batujai Dam, bioindicator, microalgae, pollution.

\section{Pendahuluan}

Bendungan Batujai merupakan salah satu bendungan yang ada di Kabupaten Lombok Tengah. Bendungan Batujai mulai beroperasi pada tahun 1982 dan dibangun dengan tujuan untuk menampung kelebihan air pada musim penghujan serta digunakan secara periodik untuk mengairi lahan pertanian beberapa desa di sekitarnya (Raiz, 2013). Bendungan Batujai memiliki luas genangan 890 ha, kedalaman ratarata 6 meter, ketinggian 92,35 Mdpl, dengan volume efektif 23,5 juta $\mathrm{m}^{3}$ (Departemen Perkerjaan Umum 2005). Air Bendungan Batujai dimanfaatkan untuk irigasi lahan pertanian, pengendalian banjir, perikanan air tawar dan pengembangan sebagai pembangkit listrik tenaga mikrohidro. Potensi tersebut menjadikan bendungan Batujai sebagai sumber pengairan yang penting di Lombok Tengah. Selain itu Bendungan Batujai juga merupakan penampung beberapa aliran sungai yaitu: Sungai Leneng, Sungai Sade dan Sungai Dodokan. Fungsi tersebut menjadikan Bendungan Batujai menjadi tempat penumpukan berbagai bentuk bahan pencemar yang terbawa oleh sungai-sungai inletnya (Achmad, 2011). Hal tersebut dapat mempengaruhi kualitas air yang masuk ke Bendungan Batujai.

Mikroalga merupakan salah satu parameter ekologi yang dapat memberikan gambaran keadaan perairan. Mikroalga juga 
termasuk salah satu komponen biotik terpenting dalam metabolisme perairan karena merupakan mata rantai primer di dalam rantai makanan (Samudra et al., 2012). Tingkat sensifitas yang tinggi terhadap adanya perubahan kandungan nutrien pada badan air yang dimiliki mikroalga dapat menjadikan mikroalga sebagai salah satu bioindikator. Kepekaan tersebut menjadikan mikroalga sebagai penanda terbaikan kualitas perairan (Rahayu et al., 2009). Berdasarkan uraian di atas dan berbagai peranan penting Mikroalga sebagai produsen primer dan dapat menjadi bioindikator kualitas perairan maka perlu dilakukan penelitian tentang Keanekaragaman mikroalga di Bendungan Batujai Lombok Tengah.

\section{Bahan dan Metode}

\section{Metode Penelitian}

Jenis penelitian ini adalah deskriptif eksploratif. Pengambilan sampel penelitian dilakukan di Bendungan Batujai, Lombok Tengah. Preparasi sampel mikroalga untuk pengamatan secara mikroskopik dan identifikasi spesies dilaksanakan di Laboratorium Biologi FKIP Universitas Mataram, adapun pengukuran parameter fisika dilaksanakan langsung di Bendungan Batujai dan pengukuran parameter kimia dilaksanakan di Balai Laboratorium Kesehatan dan Kalibrasi Nusa Tenggara Barat. Pengambilan sampel dilakukan pada bulan November 2020 sedangkan preparasi sampel mikroalga untuk pengamatan secara mikroskopik dan identifikasi spesies dilakukan pada bulan November dan Desember 2020. Pengambilan sampel dilakukan di 4 titik (Gambar 1) dengan posisi geografisnya dapat dilihat pada Tabel 1 . Populasi dalam penelitian ini adalah semua spesies mikroalga yang terdapat di Bendungan Batujai Kabupaten Lombok Tengah, sedangkan sampelnya adalah semua spesies mikroalga yang tersaring jaring plankton. Penentuan spesies mikroalga berdasarkan ciri morfologi yang tampak seperti bentuk sel, koloni, sebaran kloroplas dan jumlah seta. Sumber yang diacu untuk identifikasi spesies tersebut berpedoman pada buku Botes (2003), Bellinger dan Sigee (2010), Park (2012), Barsanti dan Gualtieri (2014), dan Sahoo dan Seckbach (2015). Faktor fisika dan kimia yang diukur dalam penelitian ini adalah suhu, $\mathrm{pH}$, dissolved oxygen (DO), BOD, fosfat dan nitrat. Pengukuran $\mathrm{pH}$ dan suhu air dilakukan secara langsung di masing-masing titik pengambilan sampel. $\mathrm{pH}$ dan Suhu diukur menggunakan alat portable $\mathrm{pH}$ meter dan Do Meter Lutron . Pengukuran kadar DO, BOD, nitrat dan fosfat dilaksanakan di Balai Laboratorium Kesehatan dan Kalibrasi Nusa Tenggara Barat. Kondisi lingkungan di lokasi penelitian dapat dilihat di Tabel 2.

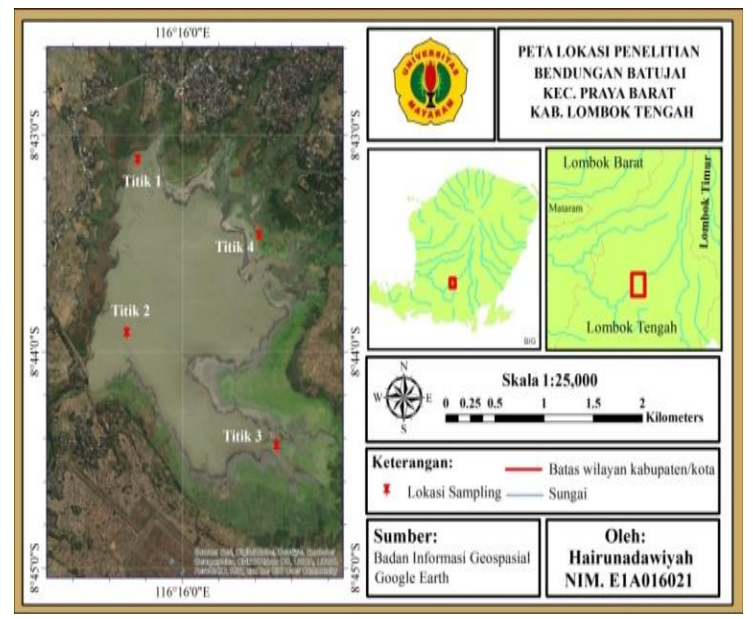

Gambar 1. Peta Lokasi titik pengambilan sampel mikroalga.

Tabel 1. Posisi Geografis Titik Sampling

\begin{tabular}{lccc}
\hline No & Titik & \multicolumn{2}{c}{ Letak Geografis } \\
\cline { 3 - 4 } & & LS & BT \\
\hline 1 & I & $8^{\circ} 72^{\prime} 29.30 " \mathrm{~S}$ & $116^{\circ} 26^{\prime} 24.26^{\prime \prime} \mathrm{E}$ \\
2 & II & $8^{\circ} 73^{\prime} 51.53^{\prime \prime} \mathrm{S}$ & $116^{\circ} 25^{\prime} 94.24 " \mathrm{E}$ \\
3 & II & $8^{\circ} 73^{\prime} 32.63 " \mathrm{~S}$ & $116^{\circ} 27^{\prime} 06.57^{\prime \prime} \mathrm{E}$ \\
4 & I & $8^{\circ} 72^{\prime} 48.21 " \mathrm{~S}$ & $116^{\circ} 26^{\prime} 98.02 " \mathrm{E}$
\end{tabular}

Keterangan: LS= Lintang Selatan, BT= Bujur Timur

Tabel 2. Kualitas lingkungan di lokasi Penelitian

\begin{tabular}{llllll}
\hline \multirow{2}{*}{ No } & Parameter & \multicolumn{4}{c}{ Titik } \\
& lingkungan & & & \\
\cline { 3 - 6 } & & I & II & III & IV \\
\hline 1 & DO & 5,76 & 2,30 & 6,91 & 5,38 \\
2 & BOD & 3,04 & 7,34 & 3,61 & 2,08 \\
3 & fosfat & 0,11 & 0,10 & 0,15 & 0,18 \\
4 & Nitrat & 0,24 & 0,24 & 0,15 & 0,30 \\
5 & pH & 6,6 & 6,4 & 7,1 & 6,9 \\
6 & Suhu & 30,5 & 29 & 31,3 & 30,7 \\
\hline
\end{tabular}


Variabel yang dihitung dalam penelitian ini meliputi kelimpahan spesies, indeks keanekaragaman dan indeks dominansi spesies.

\section{a. Kelimpahan spesies}

Perhitungan kelimpahan spesies mikroalga dilakukan dengan menghitung jumlah sel yang terdapat pada mikroalga. Mikroalga yang memiliki bentuk rantai atau berkoloni dihitung jumlah sel dalam rantai atau koloni sebagai jumlah individu. Perhitungan jumlah sel mikroalga menggunakan rumus kelimpahan atau nilai N (Romimohtarto dan Juwana, 2007).

\section{b. Indeks keanekaragaman spesies}

Indeks keanekaragaamaan spesies mikroalga dihitung dengan menggunakan rumus keanekaragam Shannon \& Wiener atau nilai H' (Odum, 1993). Indeks keanekaragaman digunakan untuk mengetahui tingkat keanekaragaman hayati dari biota yang diteliti. Apabila indeks keanekaragaman spesies semakin tinggi, berarti komunitas biota (mikroalga) di perairan tersebut semakin beragam (Romimohtarto dan Juwana, 2007).

\section{c. Indeks Dominansi spesies}

Indeks dominansi spesies digunakan untuk mengetahui spesies yang mendominasi pada suatu perairan. Keberadaan suatu spesies yang mendominasi di suatu perairan mengindikasikan bahwa perairan tersebut tercemar (Arum et al., 2017). Perhitungan nilai indeks dominansi spesies di dalam suatu peraiaran dapat diketahui dengan menggunakan indeks dominansi Simpson (Magurran, 2004).

Hasil data mikroalga yang diperoleh dianalisis secara kualitatif dan kuantitatif kemudian di deskripsi. Deskripsi parameter biologi dengan menampilkan grafik kelimpahan spesies, keanekaragaman dan dominansi yang diolah program microsoft excel 2010.

\section{Hasil dan Pembahasan}

\section{Spesies Mikroalga}

Penelitian di Bendungan batujai yang diperoleh hasil 40 Spesies, 5 kelas dan 16 ordo yang telah teridentifikasi. Adapun 5 kelas yang ditemukan terdiri dari: Bacillariophycea (6 spesies), Chlorophyceae (22 spesies), Coscinodiscophyceae (2 spesies), Cyanophyceae
(9 spesies), dan Euglenoidae (1 spesies) (Gambar 2). Ditemukannya mikroalga kelas Euglenophyceae menunjukkan bahwa banyak bahan organik yang masuk ke dalam perairan bendungan Batujai. Hal ini sejalan dengan pendapat Isnaini (2012) yang menyatakan bahwa kelas Euglenophyceae 90\% hidup di perairan tawar yang mengandung banyak bahan organik.

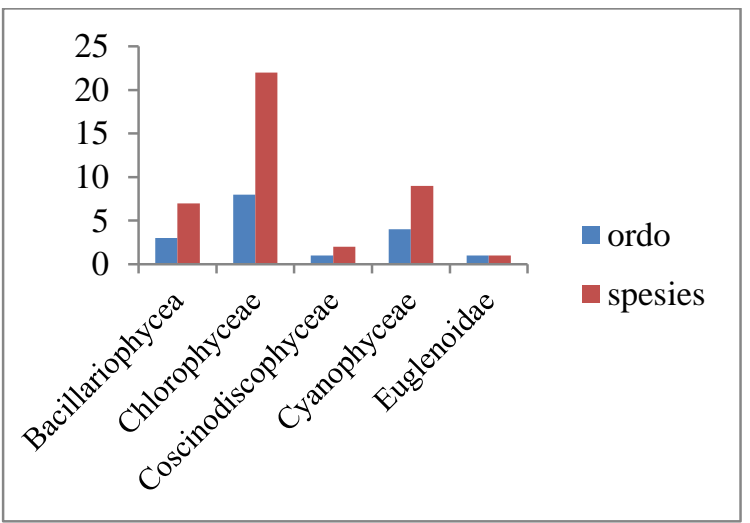

Gambar 2. Persebaran taksa yang ditemukan pada tiap kelas

Jumlah mikroalga yang diperoleh di Bendungan Batujai mengalami penurunan jumlah spesies dibandingkan dengan tahun 2013. Laporan Adawiyah (2013) menunjukkan jumlah mikroalga yang diperoleh sebanyak 49 spesies dan ditemukannya divisi Dynophyta. Mikroalga yang ditemukan di Bendungan Batujai lebih beragam dibandingkan mikroalga yang ditemukan di Bendungan Pandanduri dilaporkan oleh Zohri (2020) yakni ditemukan 31 spesies mikroalga yang terdiri dari 5 kelas dan 13 ordo. Sedangkan jumlah mikroalga Bendungan Batujai lebih rendah dibandingkan mikroalga yang ditemukan di Danau Lebo Taliwang yaitu 38 spesies dengan 10 kelas 14 ordo (Kawirian, 2016).

Penyebaran spesies mikroalga di Bendungan Batujai bervariasi disetiap titik pengamatan. Chlorophyceae memiliki jumlah ordo dan spesies terbanyak yakni 8 ordo dan 22 spesies (Gambar 2). Dari 40 spesies yang ditemukan ketika pengamatan, titik VI memiliki jumlah spesies terbanyak yakni 20 spesies mikroalga dengan Chlorophyceae sebagai kelas yang memiliki jumlah spesies tertinggi yaitu 10 spesies. Adapun titik II memiliki taksa terendah yakni 14 spesies (Gambar 3). 


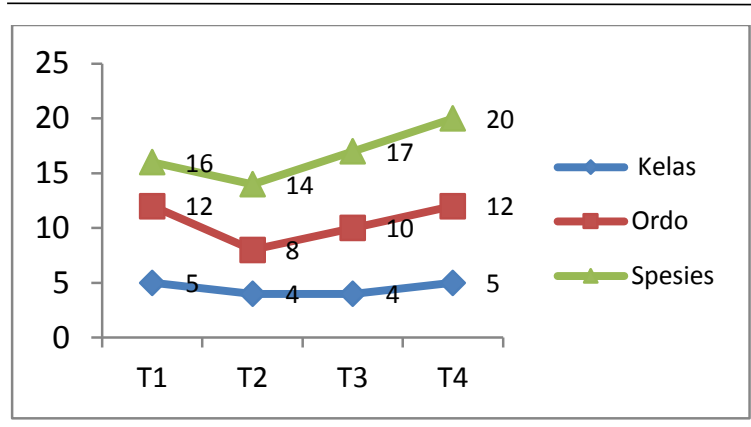

Gambar 3. Jumlah taksa dari tiap titik yang ditemukan di Bendungan Batujai

Hasil ini sejalan dengan laporan Munthe et al. (2012) yang menyatakan bahwa kelas Chlorophyceae merupakaan kelas yang paling banyak ditemukannya spesies mikroalga air tawar. Chlorophyceae adalah mikroalga yang berperan penting dalam perairan air tawar. Adapun Kelas yang memiliki jumlah individu tertinggi merupakan Cyanophyceae. Hal ini disebabkan karena adanya perbedaan daya toleransi. Aziz et al. (2015) menyatakan Cyanobacteria dan Chlorophytha merupakan jenis mikroalga dominan di perairan yang tergenang, namun karena Cyanobacteria lebih dapat bertoleransi terhadap kisaran suhu yang lebih tinggi dibandingkan dengan Chlorophyta dan Bacillariophyta, sehingga pada perairan lebih didominasi oleh mkroalga Cyanobacteria. Selain itu, tingginya jumlah individu kelas cyanophyceae diakibatkan adanya blooming dari spesies Microcystis aeruginosa. Melimpahnya mikroalga kelas Cyanophyceae dapat mengakibatkan air danau menjadi berwarna. Danau atau lautan yang awalnya memiliki warna jernih akan terlihat pekat dan kadang-kadang menjadi warna biru terang, kehijauan, abu-abu, cokelat atau merah diakibatkan karena pertumbuhan populasi yang sangat besar dari Cyanophyceae (Pal dan Choudhury 2014).

\section{Keanekaragaman Mikroalga di Bendungan Batujai}

\section{a. Kelimpahan}

Nilai Kelimpahan keseluruhan spesies mikroalga di Bedungan Batujai sebesar 8.690 Ind/L. Kelimpahan spesies mikroalga bervariasi di setiap titik yaitu titik I: 2613,33; titik II: 1230, titik III: 3400; dan titik VI: 1446,67 (Gambar 4). Nilai kelimpahan mikroalga Bendungan Batujai mengalami penurunan dibandingkan degan nilai kelimpahan mikroalga tahun 2013. Adawiyah (2013) melaporkan kelimpahan mikroalga bendungan Batujai berkisar antara 1,160-5,390. Kelimpahan mikroalga Bendungan Batujai lebih rendah dibandingkan kelimpahan mikroalga yang ditemukan di Bendungan Pandandure. Zohri (2020) melaporkan jumlah kelimpahan mikroalga yang diperoleh di Bendungan Pandandure, Lombok Timur berkisar antara $15.335,833 \mathrm{ind} / \mathrm{L}$.

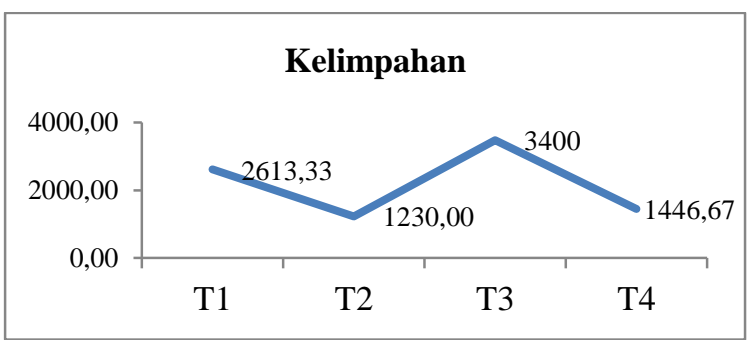

Gambar 4. Kelimpahan Spesies mikroalga (Ind/L) Bendungan Batujai

Kelimpahan spesies setiap titik pengambilan sampel di dominasi oleh spesies yang sama yaitu spesies Mikrocystis aeruginosa dan Microcystis incerta. Hasil ini sejalan degan penelitian yang dilaporakan oleh Suripto et al. (2014) yang menyatakan Microcystis aeruginosa dan Microcystis incerta merupakan fitoplankton dengan kelimpahan tertinggi di Bendungan Batujai. Melimpahnya spesies Microcystis aeruginosa dan Microcystis incerta yang tergolong Kelas Cyanophyceae juga dikarenakan Cyanophyceae memiliki kemampuan untuk mengambil nutrien seperti fosfat dan amonia pada level yang sangat rendah (Pal dan Choudhury, 2014). Selain itu, spesies mikroalga Microcystis aeruginosa dan Microcystis incerta dapat memproduksi racun yang disebut hepatotoksin menyebabkan pemecahan sel hati sehingga dapat menyebabkan kerusakan sel hati manusia (Rissik et al., 2009).

\section{b. Indeks keanekaragaman}

Indeks keanekaragaman spesies mikroalga dari seluruh titik bendungan Batujai yaitu sebesar 1,712. Indeks keanekaragaman spesies fitoplankton Bendungan Batujai di empat Titik pengambilan sampel yakni berkisar antara 0,88 1,67 . Indeks keanekaragaman spesies tertinggi terdapat di titik VI sebesar 1,67 dan Indeks keanekaragaman spesies terendah terdapat di titik II yakni 0,88 (Gambar 5). Hasil ini lebih 
rendah dibandingkan indeks keanekaragaman pada bendungan Pandanduri yaitu berkisar antara 2,256 sampai 2,626 (Zohri, 2020). Akan tetapi lebih tinggi dibandingkan indeks keanekaragaman mikroalga di sumber air panas Sebau, kawasana Taman Nasional Gunung Rinjani pada setiap titik yang berkisar antara 0,0 sampai 0,08 (Budiarsih, 2019). Barus (2002) menyatakan bahwa suatu komunitas akan mempunyai keanekaragaman spesies yang tinggi apabila terdapat banyak spesies dengan jumlah individu masing-masing spesies yang relatif merata.

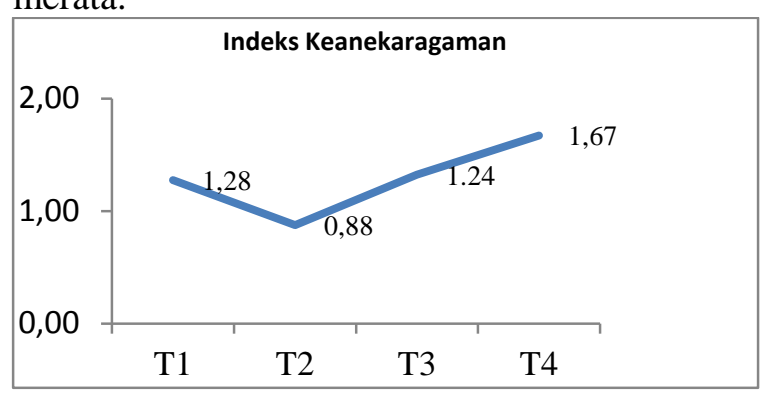

Gambar 5. Indeks Keanekaragaman Spesies mikroalga (H') Bendungan Batujai

Indeks keanekaragaman keseluruhan spesies mikroalga di Bendungan Batujai adalah 1,712 menunjukkan keanekaragaman spesies mikroalga yang terdapat di Bendungan Batujai dapat dikategorikan sedang. Hal ini berdasarkan nilai yang didapatkan saat penghitungan menggunakan indeks keanekaragaman dengan tolak ukur apabila nilai yang diperoleh berkisar 1-2,5 dikategorikan keanekaragaman sedang. Tingkat keanekaragaman sedang mengindikasikan bahwa perkembangan mikroalga disuatu perairan kurang optimal. Selain itu, kebiasaan para petani disekitar Bendungan Batujai yang menggukan pupuk kimia atau pestisida seperti pupuk urea, NPK, serta adanya limbah domestik dari penduduk dan perternakan yang masuk ke Bendungan Batujai turut mempengaruhi kualitas perairan (Achmad, 2011). Hal tersebut didukung oleh hasil pengukuran faktor lingkungan seperti suhu, $\mathrm{pH}$, DO, serta ketersediaan nutrisi seperti kandungan nitrat dan fosfat yang tergolong cukup rendah untuk pertumbuhan mikroalga sehingga potensi keberagaman spesies pada bendungan Batujai juga rendah.

\section{c. Indeks Dominansi}

Nilai keseluruhan Total indeks dominasi spesies pada bendungan Batujai sebesar 0,327. Hal ini menandakan bahwa indeks dominasi mikroalga Bendungan Batujai termasuk dalam kategori dominasi rendah, artinya tidak ada spesies yang mendominasi di Bendungan Batujai. Hal tersebut sejalan dengan Madduppa (2016) yang menyatakan bahwa jika nilai indeks dominansi spesies $0<\mathrm{D} \leq 0.5$ menandakan indeks dominasi rendah dan tidak ada spesies yang mendominasi. Berdasarkan indeks dominansi spesies tersebut, menandakan struktur komunitas mikroalga di Bendungan Batujai dalam keadaan stabil (Sari et al., 2014). Indeks dominasi spesies mikroalga Bendungan Batujai pada setiap titik pengambilan sampel bervariasi yang berkisar antara 0,30-0,67. Indeks dominasi spesies mikroalga tertinggi ditemukan pada titik II yakni 0,67 dan nilai terendah di titik VI yaitu 0,30 (gambar 6).

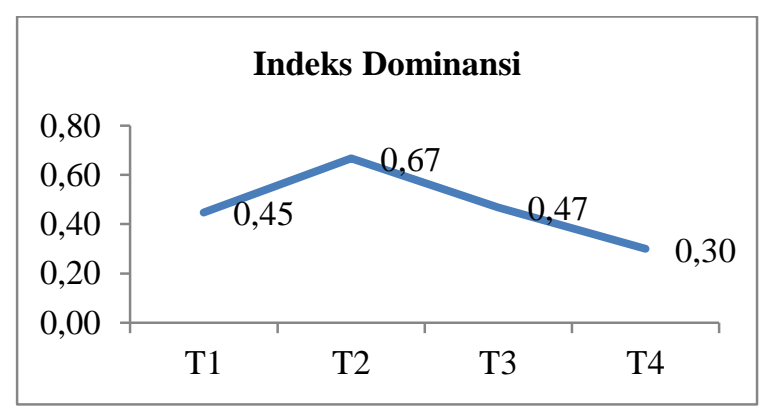

Gambar 6. Indeks Dominansi Spesies mikroalga (D) Bendungan Batujai

Nilai indeks dominansi spesies mikroalga di Bendungan Batujai lebih tinggi dibandingkan dengan indeks dominansi spesies mikroalga divisi Chlorophyta di Pandandure yang berkisar 0,10-0,16 (Zikriah, 2020). Laporan Budiarsih (2019) menyatakan indeks dominansi mikroalga air panas Sebau pada setiap titik pengamatan berkisar 0,95-1 dan indeks dominasi spesies di Aik Kalak pada setiap titik berkisar 0,22-1, nilai tersebut lebih tinggi dibandingkan indeks dominansi di Bendungan Batujai.

\section{Kualitas Air Bendungan Batujai Berdasarkan Tingkat Keanekaragaman Mikroalga}

Bendungan Batujai merupakan salah satu bendungan terbesar di Lombok yang memiliki tiga aliran sungai utama yang menjadi sumber pengairannya yaitu Sungai Leneng, Sungai Sade/ Tiwubare, dan Sungai Dodokan. Berbagai bentuk 
kegiatan masyarakat di sepanjang sisi kiri kanan aliran sungai yang masuk ke Bendungan Batujai seperti peternakan, pertanian, dan industri terus mengalami peningkatan setiap tahunnya, karenanya ketiga sungai tersebut dipastikan membawa sejumlah besar bahan organik, sedimen, dan bahan-bahan pencemar dari daerah hulu dan sepanjang aliran sungai yang akhirnya masuk ke Bendungan Batujai (Achamad, 2011). Air sungai yang masuk ke Bendungan Batujai tercemar oleh pencemar organik, mengakibatkan kualiatas air tercemar hal ini dapat dilihat dengan nilai BOD air cukup tinggi yaitu dengan nilai masing-masing berkisar antara $2,08 \mathrm{mg} / \mathrm{l}$ sampai $7,34 \mathrm{mg} / \mathrm{l}$. Nilai BOD air tersebut mengindikasi bahwa air bendungan batujai tidak layak untuk sumber baku air minum karena sudah melebihi kategori air kelas 1 menurut Peraturan Pemerintah nomor 82/2001.

Keseluruhan Indeks keanekaragaman mikroalga bendungan Batujai adalah 1,712 dengan rata-rata nilai DO yaitu 5,09 dan BOD yaitu 4,0175. Menurut Wardana (2006) keanekaragaman dengan rentang $2,0<\mathrm{H}^{\prime}<1,6$ dengan nilai DO antara 4,5-6,5 dan nilai BOD antara 3,0-4,9 termasuk dalam kategori tercemar ringan. kategori tersebut memungkinkan banyaknya pencemaran dari polutan organik yang masuk ke Bendungan Batujai. Hal tersebut dikarenakan Bendungan Batujai merupakan penampung tiga aliran sungai besar yang ada di Lombok Tengah. Sungai-sungai tersebut melewati pemukiman warga yang merupakan sumber utama polutan organik yang masuk ke Bendungan Batujai. Polutan organik juga dapat berasal dari sisa pupuk yang mengalir melalui saluran irigasi persawahan yang mengelilingi Bendungan Batujai serta adanya limbah domestik dan limbah perternakan penduduk di sekitar Bendungan Batujai.

Faktor utama yang mempengaruhi indeks keanekaragaman mikroalga dan kualitas air bendungan Batujai adalah keberadaan spesies Microcystis aeruginosa dan Microcystis incerta yang dominan Microcystis aeruginosa dan Microcystis incerta merupakan anggota kelas Cyanophyceae yang mengandung toksin. Toksin yang umumnya dihasilkan anggota kelas cyanophyceae atau cyanobacteria disebut cyanotoksin (Sahoo dan Seckbach, 2015). Cyanobacteria menghasilkan dua tipe toksin yaitu hepatotoksin dan neurotoksin.
Hepatotoksin merupakan toksin yang menyebabkan pemecahan sel hati, dan organ internal lain dari korban yang terkena racun sehingga dapat menyebabkan kematian melalui internal haemorrhage. Neurotoksin merupakan toksin yang menyerang sistem saraf, korban yang terkena racun ini bias mengalami kematian karena kerusakan sistem pernapasan. Spesies mikroalga yang mampu menghasilkan hepatotoksik yaitu Microcystis aeruginosa, Nodularia spumigena, dan Cylindrospermopsis raciborskii (Rissik et al., 2009). Selain itu kelimpahan Microcystis aeruginosa yang tinggi juga dapat menyebabkan blooming pada air (Suriawira, 1993).

Melimpahnya spesies Microcystis sp. mengindikasikan air tersebut tidak boleh di konsumsi sebagai air minum karena dapat menyebabkan kerusakan organ manusia yaitu kerusakan sel hati (Rissik et al., 2009). Selain itu indikasi pencemaran air di Bendungan Batujai juga dikarenakan ditemukannya spesies Nitzschia sp., Anabaena sp., Osillatoria sp. dan Spirogyra sp. Hal ini sejalan dengan laporan Suriawira (1993) dimana spesies mikroalga yang dapat menyebabkan pencemaran di dalam perairan adalah kelompok mikroalga Phormidium, Nitzschia, Euglena, Osillatoria, Spirogyra, dan Lyngbya. Sehingga kelayakan air di Bendungan Batujai dapat diperuntukkan untuk kegiatan pembudidayaan ikan air tawar, perternakan dan irigasi pertanian.

\section{Kesimpulan}

Berdasarkan hasil penelitian dapat disimpulkan bahwa: (1) Kelimpahan spesies bendungan Batujai yaitu 8.690 Ind/L, Indeks keanekaragaman mikroalga bendungan Batujai adalah 1,712 dengan indeks Dominansi spesies 0,327 yang menandakan struktur komunitas mikroalga di Bendungan Batujai dalam keadaan stabil (2) Kualitas air di Bendungan Batujai tergolong dalam perairan tercemar ringan, sehingga peruntukan untuk pemanfaatan air di Bendungan Batujai layak digunakan untuk kegiatan pembudidayaan ikan air tawar, perternakan, dan irigasi pertanian. Tidak disarankan untuk sumber air minum dan prasarana/sarana rekreasi air.

\section{Ucapan Terima Kasih}


Ucapan terima kasih dari tim penelitian sampaikan kepada Dekan FKIP Universitas Mataram yang telah memberikan fasilitas laboratorium untuk pelaksaan penelitian dan semua pihak yang mendukung keberhasilan penelitian

\section{Referensi}

Achmad, F. (2011). Dampak Pencemaran Lingkungan Kota Praya Terhadap Kualitas Air Waduk Batujai. Buletin Geologi Tata Lingkungan, $21(2), \quad 69-82$. https://adoc.pub/dampak-pencemaranlingkungan-kota-praya-terhadap-kualitasai.html

Adawiyah, B.S.R. (2013). Keragaman Spesies Mikroalga Di Perairan Waduk Batujai Dan Waduk Pengga Kabupaten Lombok Tengah. Hasil Riset tidak Dipublikasi sebagai Syarat Gelar Sarjana, Universitas Mataram, Mataram, Indonesia.

Arum, O., Piranti, A. S., \& Christiani. (2017). Tingkat pencemaran Waduk Penjalin Kecamatan Paguyangan Kabupaten Brebes ditinjau dari struktur komunitas plankton. Scripta Biologica, 4(1), 53-59. https://doi.org/10.20884/1.sb.2017.4.1.38 6

Aziz, R.., Nirmala K., Affandi, R. \& Prihadi, T. (2015). Kelimpahan Fitoplankton Penyebab Bau Lumpur pada Bludidaya Ikan Bandeng Menggunakan Pupuk N:P Berbeda. Jurnal Akuakultur Indonesia, 14(1), 58-68. https://doi.org/10.19027/jai.14.58-68

Barsanti, L. \& Gualtieri, P. (2014). Algae Aanatomy, Biochemistery, and Biotechnelogy Second Edition. Pisa: CRC Press.

Barus, IT. A. (2000). Impact of Human Activities on the Development of Environmental Factors in Belawan River. URGE Project Batch III.

Bellinger, E. G. \& Sigee, D. C. (2010). Freshwater Algae Identification and Use as Bioindicators. USA: John Wiley \& Sons, Ltd.

Botes, L. (2003). Phytoplankton Identification Catalogue. Saldanha Bay, South Africa,
April 2001. GloBallast Monograph Series No. 7. IMO London.

Budiarsih, T. (2019). Keanekaragaman Mikroalga Pada Sumber Air Panas Di Kawasan Taman Nasional Gunung Rinjani Sebagai Bahan Tambahan Praktikum Botani Tingkat Rendah. Hasil Riset tidak Dipublikasi sebagai Syarat Gelar Sarjana, Universitas Mataram, Mataram, Indonesia.

Departemen Perkerjaan Umum (2005). Studi Keseimbngan Air Waduk Batujai Untuk Pembangkit Listrik Mikrohidro Dan Irigasi Pompa Dongkak Langit. Laporan Teknis Proyek Pengembangan Dan Konservasi Sumber Air Lombok Dan Sumbawa.

Isnaini (2012). Struktur Komunitas Fitoplankton di Perairan Muara Sungai Banyuasin Kabupaten Banyuasin Sumatera Selatan. Maspari Journal, 4(1), 58-68. https://ejournal.unsri.ac.id/index.php/mas pari/article/download/1342/476

Kawirian, R. R., Mahrus, \& Japa, L. (2016). Struktur komunitas fitoplankton Danau Lebo Taliwang Sumbawa Barat. Prosiding Seminar Nasional Pendidikan Biologi, (hal. 50-59). Mataram: Universitas Mataram.

http://jurnalfkip.unram.ac.id/index.php/Se mnasBIO/article/view/634

Madduppa, H. (2016). Modul Pelatihan: Teknik Analisis Kuantitatif Data. Bogor: Departemen Ilmu dan Teknologi Kelautan IPB.

Magurran, A. E. (2004). Measuring Biological Diversity. Australia: Blackwell Publishing Company.

Munthe, Yunita. V., Aryawati, dan Isnaini. (2012). Struktur Komunitas dan Sebaran Fitoplankton di Perairan Sungsang Sumatera Selatan. Maspari Journal, 4(1), 122-130.

https://ejournal.unsri.ac.id/index.php/mas pari/article/view/1437

Odum, E.P. (1993). Dasar-Dasar Ekologi. Edisi ketiga. Jogjakarta: Gajah Mada University Press.

Pal, R. \& Choudhury, A. K. (2014). An Introduction to Phytoplanktons: Diversity and Ecology. India: Springer. 
Park, J. G. (2012). Algal Flora of Korea. Volume 5 Number 1. Cyanophyta: Cyanophyceae: Chroococcales, Oscillatoriales Freshwater Cyanoprokaryota I. Korea:Junghaengsa, Inc.

Rahayu S., Widodo R. H., Van Noordwijk M., Suryadi I., \& Verbist B. (2009). Monitoring air di daerah aliran sungai.World Agroforestry CentreSoutheast Asia Regional Office. Bogor, Indonesia.

Raiz, F.J. (2013). Bendungan Batujai. Kementerian Pekerjaan Umum Dirjen Sumber daya Air Balai Wilayah Sungai NTB. Indonesia.

Rissik, D., Senden, D., Doherty, M., Ingleton, T., Ajani, P., Bowling, L., Gibbs, M., Gladstone, M., Kobayashi, T., Suthers, I., dan Froneman, W. (2009). Plankton: a Guide to Their Ecology and Monitoring for Water Quality editors by Iain M. Suthers and David Rissik. Australia: CSIRO Publishing

Romimuhtarto, K. \& Juwana, S. (2007). Biologi Laut Ilmu Pengetahuan tentang Biota Laut. Jakarta: Djambatan.

Sahoo, D. \& Seckbach, J. (2015). The Algae World. New York London: Springer.

Samudra, S.R., Tri, R.S., \& Munifatul, I. (2012). Komposisi, Kemelimpahan dan Keanekaragaman Fitoplankton Danau Rawa Pening Kabupaten Semarang. Bioma, 15(1), 6-13. https://doi.org/10.14710/bioma.15.1.6-13

Sari, A. N., Hutabarat, S. \& Soedarsono, P. (2014). Struktur komunitas plankton pada padang lamun di Pantai Pulau Panjang, Jepara. Diponegoro Journal of Maquares Management of Aquatic Resources, 3(2), 82-91. https://doi.org/10.14710/marj.v3i2.5006

Suriawiria, U. (1993). Mikrobiologi Air. Bandung: Alumni

Suripto, Japa, L. \& Gunawan, E. R. (2014). Konsorsium Mikroalga Untuk Produksi Minyak Biodiesel. Jurnal Biologi Tropis, 14(1), 31-35. https://jurnalfkip.unram.ac.id/index.php/J BT/article/download/208/204

Wardhana, W. (2006). Metode Prakiraan Dampak dan Pengelolaannya pada Komponen Biota Akuatik. Jakarta: Pusat
Penelitian Sumberdaya Manusia dan Lingkungan UI.

Zikriah, Bachtiar, I. \& Japa, L. (2020). The Community of Chlorophyta as Bioindicator of Water Pollution in Pandanduri Dam District of Terara East Lombok. Jurnal Biologi Tropis, 20(3):546-555. https://doi.org/10.29303/jbt.v20i3.2344

Zohri, L.H.N., Idrus, A.A. \& Japa, L. (2020). Phytoplankton Diversity as Bioindicator of Pandanduri Dam Waters, East Lombok Regency. Jurnal Biologi Tropis, 20(3):355-362. https://doi.org/10.29303/jbt.v20i3.2024 